\title{
SEALING AND EXPLANT TYPES ON THE MANGABA MICROPROPAGATION
}

\section{Tipo de vedação e explantes na micropropagação de mangabeira}

\author{
Aline de Jesus Sá1, Ana da Silva Lédo ${ }^{2}$, Carlos Alberto da Silva Lédo 3 , Moacir Pasqual ${ }^{4}$, \\ Ana Veruska Cruz da Silva ${ }^{5}$, Josué Francisco da Silva Junior ${ }^{5}$
}

\begin{abstract}
In micropropagation, especially for mangaba tree botanical variety of Northeastern Brazil, limiting aspects such as ethylene accumulation in the cultivation flask and loss of vigor in subcultures have been observed. This study was aimed at assessing the technical and scientific knowledge of the in vitro propagation of botanical mangaba tree variety and at improving the micropropagation protocol, establishing the in vitro cultivation time, the best type of flask sealing and explant at different micropropagation stages. For the establishment phase and for the first and second subcultures, the MS medium with $3 \%$ sucrose and $0.6 \%$ agar, supplemented with $1 \mathrm{mg} \mathrm{L}^{-1}$ IAA and $1 \mathrm{mg} \mathrm{L}^{-1}$ BA was used. Evaluations were performed at 30, 50 and 65 days of in vitro cultivation. The best types of flask sealing for the establishment phase were the PVC film and Para-film ${ }^{\circledR}$ and for the first subculture the Para-film ${ }^{\circledR}$ seal. In the second subculture the PVC film and Para-film ${ }^{\circledR}$ seals promoted the best growth. The median and basal nodal segments presented the best performance in the first subculture. No significant effect of explant type was observed in the second subculture. The ideal subculture interval in the establishment phase and the first and second subcultures is 50 days.
\end{abstract}

Index terms: Hancornia speciosa, tissue culture, in vitro ethylene, nodal segments.

\section{RESUMO}

Na micropropagação, especialmente para mangaba, variedade botânica da árvore do Nordeste do Brasil, aspectos limitantes, como acúmulo de etileno no recipiente de cultivo e perda de vigor em subculturas têm sido observados. Neste estudo, objetivou-se avaliar o conhecimento técnico e científico da propagação in vitro de mangabeira, variedade botânica do Nordeste do Brasil, e melhorar o protocolo de micropropagação, o melhor tipo de vedação frasco e explante em diferentes etapas. Para a fase de estabelecimento e para as subculturas primeiro e segundo, foi utlizado o meio MS com 3\% de sacarose e agar $0,6 \%$, suplementado com $1 \mathrm{mg} \mathrm{L}^{-1}$ de AIA e $1 \mathrm{mg} \mathrm{L}^{-1}$ de BAP. As avaliações foram realizadas aos 30, 50 e 65 dias de cultivo in vitro. Os melhores tipos de vedação para a fase de estabelecimento foram o filme PVC e Para-filme ${ }^{\circledR} \mathrm{e}$, para o primeiro subcultivo, o Para-filme ${ }^{\circledR}$. No segundo subcultivo, o filme PVC e Para-filme ${ }^{\circledR}$ promoveram o melhor crescimento in vitro. Os segmentos nodais médio e basal apresentaram melhor desempenho no primeiro subcultivo. Nenhum efeito significativo do tipo de explante foi observado no segundo subcultivo. O intervalo de tempo ideal para as fases de estabelecimento, primeiro e segundo subcultivos é de 50 dias.

Termos para indexação: Hancornia speciosa, cultura de tecidos, etileno in vitro, segment nodal.

(Received in april 1, 2012 and approved in july 3, 2012)

\section{INTRODUCTION}

Mangaba tree is a fruit plant native of Brazil, whose occurrence is reported in several regions of the country, being mainly associated with restinga vegetation, and inland and coastal savanna (SILVA JUNIOR et al., 2006). The species has high potential for immediate use among the native fruits of northeastern Brazil (FERREIRA et al., 2005).

Given that the mangaba tree native of northeastern Brazil, botanical variety Hancornia speciosa var. speciosa Gomes, has limitations for asexual propagation using traditional methods and that its germplasm is under serious theat of genetic erosion, the in vitro propagation for the multiplication of genotypes of interest, as well as the production of seedlings with desirable phytosanitary and production features and in vitro conservation become vital. Studies have elucidated some aspects of the process of in vitro propagation of native mangaba trees in Northeastern and Midwestern Brazil such as the in vitro germination, type and concentration of plant growth regulators and culture medium to induce organogenesis and rhizogenesis (PINHEIRO et al., 2001;

\footnotetext{
'Universidade Federal de Sergipe/UFS - NEREN - São Cristóvão - SE - Brasil

${ }^{2}$ Empresa Brasileira de Pesquisa Agropecuária/Embrapa - Tabuleiros Costeiros - Avenida Beira Mar - 3250 - Praia 13 de Julho - 49025-040 - Aracaju - SE - Brasil - analedo@cpatc.com.br

${ }^{3}$ Empresa Brasileira de Pesquisa Agropecuária/Embrapa - Mandioca e Fruticultura - Cruz das Almas - BA - Brasil

${ }^{4}$ Universidade Federal de Lavras/UFLA - Departamento de Agricultura/DAG - Lavras - MG - Brasil

${ }^{5}$ Empresa Brasileira de Pesquisa Agropecuária/Embrapa - Tabuleiros Costeiros - Aracaju - SE - Brasil
}

Ciênc. agrotec., Lavras, v. 36, n. 4, p. 406-414, jul./ago., 2012 
MACHADO et al., 2004; LEMOS et al., 2006; LÉDO et al., 2007; SOARES et al., 2007).

In micropropagation, especially for mangaba tree botanical variety of Northeastern Brazil, limiting aspects such as ethylene accumulation in the cultivation receptacle and loss of vigor in subcultures have been observed (LEMOS et al., 2006). Ethylene accumulation has an adverse effect on plant development, affecting differentiation, development, morphology and growth, decreasing leaf expansion and length of shoots, inhibiting the regeneration of new shoots and causing apical necrosis (BIDDINGTON, 1992 cited by ERIG; SCHUCH, 2005), and promoting leaf abscission in in vitro cultivation. The use of more permeable flask sealing caps has promoted an increase in $\mathrm{CO}_{2}$ concentration and, simultaneously, a reduction in relative humidity and ethylene concentration (KOZAI; NGUYEN, 2003; SANTANA et al., 2008), enabling gas exchange (SANTANA et al., 2011).

Studies on the ethylene metabolism and in vitro leaf abscission control by inhibiting the production of this growth regulator in mangaba tree have been conducted (PEREIRA NETTO, 2001; PEREIRA NETTO; MCCOWN; PHARIS, 2003).

This work was aimed at assessing the technical and scientific knowledge of the in vitro propagation of botanical mangaba tree variety of northeastern Brazil, and at improving the micropropagation protocol, establishing the in vitro cultivation time, the best type of flask sealing and explant at different micropropagation stages.

\section{MATERIALS AND METHODS}

To study the in vitro propagation, nodal segments from seedlings aseptically germinated in vitro with eight months of cultivation were used. Seeds were collected from ripe fruits of the native population of mangaba trees from the Experimental Field of the Embrapa Tabuleiros Costeiros at Itaporanga d'Ajuda, State of Sergipe, Brazil.

The $\mathrm{pH}$ of media was adjusted to 5.8 before autoclaving at $120^{\circ} \mathrm{C}$ for 15 minutes. After inoculation, the cultures were maintained in a growth room with temperature of $26^{\circ} \mathrm{C} \pm 2^{\circ} \mathrm{C}$, air relative humidity averaging around $70 \%$ and 12-hour photoperiod of cold white light (photosynthetic active radiation of $52 \mu \mathrm{mol} \mathrm{m}^{-2} \mathrm{~s}^{-1}$ ).

\section{In vitro establishment}

In the establishment phase, nodal segments were inoculated into $250 \mathrm{~mL}$ glass flasks containing $30 \mathrm{~mL}$ of Murashige and Skoog culture medium (MS) with 3\% sucrose and $0.6 \%$ agar supplemented with $1 \mathrm{mg} \mathrm{L}^{-1}$ indole acetic acid (IAA) and $1 \mathrm{mg} \mathrm{L}^{-1}$ benzylaminopurine (BA). The following types of flask seals were evaluated: screw plastic cap, PVC film, Para-film ${ }^{\circledR}$ and aluminum foil. The experiment was conducted in split plot in time, with four types of seal per plot and three assessment times per subplot (30, 50 and 65 days), with six replications. Each experimental unit consisted of four flasks containing two nodal segments each.

\section{First subculture}

For the first subculture in the multiplication phase, nodal segments excised from apical, median and basal positions of shoots from the previous experiment were transferred into $30 \mathrm{~mL}$ glass flasks with MS medium added of $3 \%$ sucrose and $0.6 \%$ agar, supplemented with $1 \mathrm{mg} \mathrm{L}^{-1}$ IAA and $1 \mathrm{mg} \mathrm{L}^{-1} \mathrm{BA}$. The experiment was conducted in split plot in time, with plot of $4 \times 3$ factorial (four types of flask seals combined with three positions of nodal segments) and three assessment times per subplot, with five replicates. Each experimental unit consisted of four flasks containing two nodal segments each.

\section{Second subculture}

For the second subculture in the multiplication phase, nodal segments excised from apical, median and basal positions of shoots from the first subculture were transferred into $30 \mathrm{~mL}$ glass flasks with MS medium added of $3 \%$ sucrose and $0.6 \%$ agar, supplemented with $1 \mathrm{mg} \mathrm{L}^{-1}$ IAA and $1 \mathrm{mg} \mathrm{L}^{-1} \mathrm{BA}$. The experiment was conducted in split plot in time, with plot of $4 \times 3$ factorial (four types of flask seals combined with three positions of nodal segments) and three assessment times per subplot, with five replicates. Each experimental unit consisted of four flasks containing two nodal segments each.

At 30, 50 and 65 days after inoculation, the number of shoots per nodal segment, number of nodes per adventitious shoot and leaf abscission percentage were analyzed. The leaf abscission data were transformed into $\operatorname{root}(\sqrt{\mathrm{x}}+0.5)$. At 65 days of inoculation, the culture medium volume reduction percentage by evaporation compared to the initial culture medium volume was evaluated. This reduction was determined by the difference between the height in the flask corresponding to the initial culture medium volume $(30 \mathrm{ml})$ in the flask and at 65 days of inoculation.

All data, were analyzed for variance and averages were compared by the Tukey test at $5 \%$ probability. Statistical analyzes were performed using the SISVAR statistical software (FERREIRA, 2011). 


\section{RESULTSAND DISCUSSION}

\section{In vitro establishment}

A significant interaction of in vitro cultivation time and type of flask seal for all traits evaluated was observed. There was a significant increase in the number of adventitious shoots per nodal segment in function of the cultivation time in flasks sealed with plastic cap and aluminum foil (Table 1).

For the PVC film, the number of adventitious shoots regenerated in vitro was the same over time (Figure 1) and for the Para-film ${ }^{\circledR}$ at 30 and 50 days, with a decrease for this variable at 65 days due to the loss of shoots.

No significant difference in the number of shoots in function of the type of flask sealing in the establishment phase was observed.

There was an increase in the number of nodes per adventitious shoot after 30 days of in vitro cultivation in all types of flask sealing. At 65 days, the increase in the number of nodes was significant; however, lower than that observed at 50 days. The average number of nodes is an important variable for estimating the in vitro multiplication rate of mangaba tree, since the explant to be used in subcultures is the nodal segment.

Significant effects of the type of flask sealing on the number of nodes were detected only at 65 days, with higher average number of nodes in shoots kept in flasks with PVC film and Para-film ${ }^{\circledR}$ when compared to aluminum foil, and this was not statistically different from the plastic cap. The type of flask sealing interferes with the incidence of light in cultures. Probably there was a lower incidence of light and decreased gas exchange inside flasks sealed with plastic cap and aluminum foil, contributing to the smaller number of nodes observed.

The types of flask sealing showed no significant differences between each other for variable leaf abscission. However, this variable increased significantly with the in vitro cultivation time. The closed environment to which seedling or explants are submitted provides, in general, ethylene accumulation. This growth regulator, even in small concentrations, can be physiologically active and trigger various processes, among them leaf abscission (KERBAUY, 2004).

Table 1 - Average number of adventitious shoots per nodal segment, number of nodes per adventitious shoot and leaf abscission asa function of the in vitro cultivation time and type of flask sealing at the establishment stage of Hancornia speciosa Gomes explants.

\begin{tabular}{|c|c|c|c|c|}
\hline \multirow{2}{*}{$\begin{array}{l}\text { In vitro cultivation } \\
\text { time(days) }\end{array}$} & \multicolumn{4}{|c|}{ Type of flask sealing } \\
\hline & Plastic cap & PVC film & Para-film ${ }^{\circledR}$ & Aluminum foil \\
\hline \multicolumn{5}{|c|}{ Number of adventitious shoots } \\
\hline 30 & $3.00 \mathrm{bA}$ & $3.46 \mathrm{aA}$ & $3.63 \mathrm{aA}$ & $3.31 \mathrm{bA}$ \\
\hline 50 & $3.13 \mathrm{abA}$ & $3.46 \mathrm{aA}$ & $3.63 \mathrm{aA}$ & $3.36 \mathrm{abA}$ \\
\hline 65 & $3.20 \mathrm{aA}$ & $3.46 \mathrm{aA}$ & $3.16 \mathrm{bA}$ & $3.53 \mathrm{aA}$ \\
\hline \multicolumn{5}{|c|}{$\mathrm{VC}(\%)=4.21$} \\
\hline \multicolumn{5}{|c|}{ Number of nodes } \\
\hline 30 & $7.73 \mathrm{cA}$ & $7.46 \mathrm{cA}$ & $7.46 \mathrm{cA}$ & $6.66 \mathrm{cA}$ \\
\hline 50 & $13.90 \mathrm{bA}$ & $14.83 \mathrm{bA}$ & $13.66 \mathrm{bA}$ & $10.60 \mathrm{bA}$ \\
\hline 65 & $16.76 \mathrm{aAB}$ & $18.30 \mathrm{aA}$ & $18.20 \mathrm{aA}$ & $13.70 \mathrm{aB}$ \\
\hline \multicolumn{5}{|c|}{$\mathrm{VC}(\%)=8.60$} \\
\hline \multicolumn{5}{|c|}{ Leaf abscission $^{1}(\%)$} \\
\hline 30 & $4.42 \mathrm{bA}$ & $2.91 \mathrm{bA}$ & $0.0 \mathrm{cA}$ & $1.34 \mathrm{bA}$ \\
\hline 50 & $8.97 \mathrm{abA}$ & $9.65 \mathrm{aA}$ & $9.33 \mathrm{bA}$ & $7.94 \mathrm{aA}$ \\
\hline 65 & $10.74 \mathrm{aA}$ & $10.18 \mathrm{aA}$ & $15.45 \mathrm{aA}$ & $11.75 \mathrm{aA}$ \\
\hline \multicolumn{5}{|c|}{$\mathrm{VC}(\%)=18.90$} \\
\hline
\end{tabular}

Means followed by same small letter in the column and capital on the line do not differ statistically between each other by the Tukey test at $5 \%$ probability.

${ }^{1}$ square root-transformed data $(\mathrm{x}+0.5)$

Ciênc. agrotec., Lavras, v. 36, n. 4, p. 406-414, jul./ago., 2012 


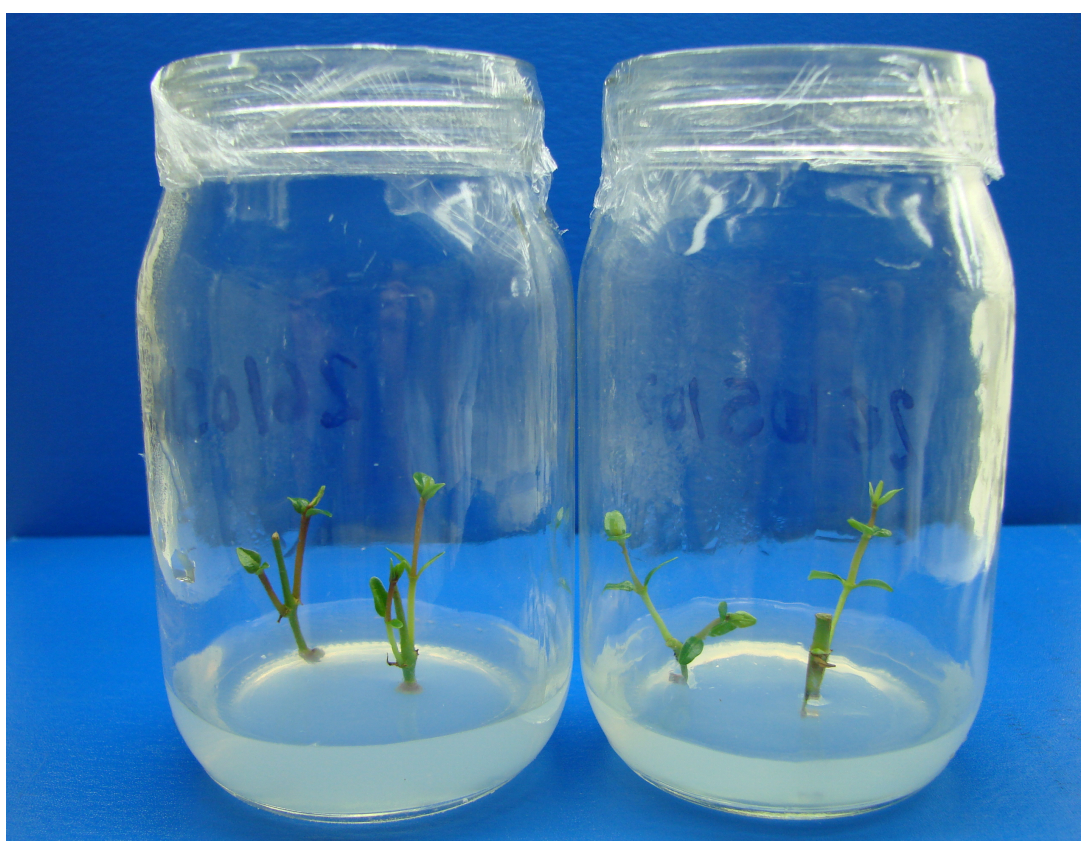

Figure 1 - Mangaba adventitious shoots regenerated in vitro in flaskes sealing PVC film in the establishment phase at 30 days.

\section{First subculture}

Significant differences were observed in the average number of shoots per nodal segment in function of the type of flask sealing after 50 days (Table 2). Para-film ${ }^{\circledR}$ showed the best results for this variable and did not differ from aluminum foil and PVC film at 50 days and only from aluminum foil at 65 days. Seals that are airtight favor ethylene accumulation that even in small concentrations can prevent the proliferation of lateral branches in mangaba tree. According to Pereira Netto (2001), the growth of aerial parts in mangaba tree in atmosphere enriched with $1 \mu \mathrm{L} \mathrm{L}^{-1}$ of ethylene results in a reduction of $50 \%$ in the proliferation of lateral branches. The average number of nodes per adventitious shoot increased significantly in function of the in vitro cultivation time; however, the increases observed at 50 days were lower than those observed in the establishment phase. Para-film ${ }^{\circledR}$ showed the best results for this variable, and did not differ from PVC film at 50 days and from plastic cap at 65 days.

There was no significant increase in the average number of shoots per nodal segment over the in vitro cultivation time, and a decrease in the numerical values for this variable when compared to the establishment phase was observed, agreeing with reports by Lemos et al. (2006).
There was no significant effect on leaf abscission in function of the type of flask sealing, and lower values for this variable when compared to the establishment phase were observed. When grown in vitro, some woody species show leaf abscission in response to the environment that they are submitted; and as a result of leaf abscission, the in vitro growth is reduced and the explant becomes fragile, impairing the micropropagation process (LEMOS; BLAKE, 1994; LEMOS et al., 2006).

There was no significance for the average number of adventitious shoots in function of the type of nodal segment. These results disagree with Nicoloso and Erig (2002), who observed higher number of shoots and the highest multiplication rate from basal nodal segments of Brazilian ginseng (Pfaffia glomerata). Median and apical segments were more efficient in 'Cleópatra' variety of tangerine (Citrus reshni Hort. ex Tan.) (SILVA et al., 2005). Median and basal segments induced adventitious shoots with higher number of nodes when compared to those formed from apical segments at 65 days. Greater leaf abscission was observed only at 30 days of in vitro cultivation for apical segments, when compared to basal and medial segments. Probably adventitious shoots regenerated from the apical portion are less vigor and thus more sensitive to ethylene accumulation. 
Table 2 - Average number of adventitious shoots per nodal segment, number of nodes per adventitious shoot and leaf abscission in function of the in vitro cultivation time and type of flask sealing and position of the nodal segments in the first subculture of Hancornia speciosa Gomes explants.

\begin{tabular}{|c|c|c|c|c|}
\hline \multirow{2}{*}{$\begin{array}{l}\text { In vitro cultivation time } \\
\text { (days) }\end{array}$} & \multicolumn{4}{|c|}{ Type of flask sealing } \\
\hline & Plastic cap & PVC film & Para-film $^{\circledR}$ & Aluminum foil \\
\hline \multicolumn{5}{|c|}{ Number of adventitious shoots } \\
\hline 30 & $1.06 \mathrm{aA}$ & $1.20 \mathrm{aA}$ & $1.35 \mathrm{aA}$ & $1.10 \mathrm{aA}$ \\
\hline 50 & $1.15 \mathrm{aB}$ & $1.18 \mathrm{aAB}$ & $1.50 \mathrm{aA}$ & $1.25 \mathrm{aAB}$ \\
\hline 65 & $1.08 \mathrm{aB}$ & $1.13 \mathrm{aB}$ & $1.51 \mathrm{aA}$ & $1.25 \mathrm{aAB}$ \\
\hline \multicolumn{5}{|c|}{$\mathrm{VC}(\%)=15.92$} \\
\hline \multicolumn{5}{|c|}{ Number of nodes } \\
\hline 30 & $3.93 \mathrm{cAB}$ & $5.33 \mathrm{cA}$ & $4.70 \mathrm{cAB}$ & $3.16 \mathrm{cB}$ \\
\hline 50 & $6.35 \mathrm{bBC}$ & $6.76 \mathrm{bAB}$ & $8.05 \mathrm{bA}$ & $5.05 \mathrm{bC}$ \\
\hline 65 & $8.20 \mathrm{aAB}$ & $7.76 \mathrm{aAB}$ & $9.11 \mathrm{aA}$ & $7.03 \mathrm{aB}$ \\
\hline \multicolumn{5}{|c|}{$\mathrm{VC}(\%)=18.11$} \\
\hline \multicolumn{5}{|c|}{ Leaf abscission $^{1}(\%)$} \\
\hline 30 & $1.40 \mathrm{aA}$ & $2.82 \mathrm{bA}$ & $2.78 \mathrm{aA}$ & $4.05 \mathrm{aA}$ \\
\hline 50 & $3.00 \mathrm{aA}$ & $5.60 \mathrm{abA}$ & $4.33 \mathrm{aA}$ & $5.25 \mathrm{aA}$ \\
\hline 65 & $3.68 \mathrm{aA}$ & $6.56 \mathrm{aA}$ & $5.37 \mathrm{aA}$ & $4.70 \mathrm{aA}$ \\
\hline \multicolumn{5}{|c|}{$\mathrm{VC}(\%)=36.59$} \\
\hline \multirow{2}{*}{$\begin{array}{c}\text { In vitro cultivation time } \\
\text { (days) }\end{array}$} & \multicolumn{4}{|c|}{ Position of the nodal segment (polarity) } \\
\hline & Apical & & Median & Basal \\
\hline \multicolumn{5}{|c|}{ Number of shoots } \\
\hline 30 & $1.13 \mathrm{bA}$ & & $1.26 \mathrm{aA}$ & $1.13 \mathrm{aA}$ \\
\hline 50 & $1.32 \mathrm{aA}$ & & $1.28 \mathrm{aA}$ & $1.20 \mathrm{aA}$ \\
\hline 65 & $1.17 \mathrm{bA}$ & & $1.31 \mathrm{aA}$ & $1.25 \mathrm{aA}$ \\
\hline \multicolumn{5}{|c|}{$\mathrm{VC}(\%)=15.92$} \\
\hline \multicolumn{5}{|c|}{ Number of nodes } \\
\hline 30 & $4.00 \mathrm{bA}$ & & $4.80 \mathrm{cA}$ & $4.05 \mathrm{cA}$ \\
\hline 50 & $6.17 \mathrm{aA}$ & & $6.90 \mathrm{bA}$ & $6.58 \mathrm{bA}$ \\
\hline 65 & $6.82 \mathrm{aB}$ & & $8.90 \mathrm{aA}$ & $8.36 \mathrm{aA}$ \\
\hline \multicolumn{5}{|c|}{$\mathrm{VC}(\%)=18.11$} \\
\hline \multicolumn{5}{|c|}{ Leaf abscission $^{1}(\%)$} \\
\hline 30 & $5.56 \mathrm{aA}$ & & $1.72 \mathrm{bB}$ & $1.01 \mathrm{bB}$ \\
\hline 50 & $4.70 \mathrm{aA}$ & & $4.15 \mathrm{abA}$ & $4.79 \mathrm{aA}$ \\
\hline 65 & $6.23 \mathrm{aA}$ & & $4.89 \mathrm{aA}$ & $4.12 \mathrm{aA}$ \\
\hline
\end{tabular}

Means followed by same small letter in the column and capital on the line do not differ statistically between each other by the Tukey test at $5 \%$ probability.

${ }^{1}$ square root-transformed data $(\mathrm{x}+0.5)$ 


\section{Second subculture}

Similarly to the first subculture, the average number of shoots in the second subculture was not influenced by time up to 65 days. Para-film ${ }^{\circledR}$ sealing also showed higher average number of shoots, not differing statistically from PVC film at 50 days and from aluminum foil at 65 days (Table 3). The type of flask sealing influences the aeration and the incidence of light to the plants. Seals that are not airtight allow greater gas exchange between atmospheric air and the environment inside the flask, allowing better transpiration of leaves and preventing ethylene accumulation, which may be harmful to the in vitro multiplication (BUFFA et al., 2002).

In thyme micropropagation (Thymus vulgaris L.), Bandeira et al. (2007) obtained better results in flasks sealed with cotton in agreement with results obtained by Santana et al. (2011), who observed higher in vitro growth of pondapple shoots (Annona glabra L.) kept in flasks sealed with cotton caps. Santana et al. (2008) obtained greater root growth of pond-apple kept in flasks sealed with plastic cap without PVC film. In potato seedlings cultivated in vitro (Solanum tuberosum L.), sealing ventilated with polyethylene membrane promoted greater leaf length (MOHAMED; ALSADON, 2010).

The average number of nodes increased over time for all types of sealing; however, the increases were lower than those observed in the first subculture. Comparatively, flasks sealed with Para-film ${ }^{\circledR}$ showed higher number of nodes per adventitious shoot and did not differ statistically from PVC film and plastic cap.

At 65 days, flasks with plastic caps showed the highest leaf abscission values. The reduction in the culture medium volume was higher for flasks sealed with PVC film when compared to plastic cap, Para-film ${ }^{\circledR}$ and aluminum foil (Table 4).

In the work conducted with Herreria sarsaparilla Martius, Gonçalves et al. (2008) found that the reduction in the culture medium volume in flasks sealed with PVC film is associated with loss of water and directly related to the evapotranspiration of explants. Although the reduction

Table 3 - Average number of adventitious shoots per nodal segment, number of nodes per adventitious shoot and leaf abscission in function of the in vitro cultivation time and type of flask sealing in the second subculture of Hancornia speciosa Gomes explants.

\begin{tabular}{|c|c|c|c|c|}
\hline \multirow{2}{*}{$\begin{array}{c}\text { In vitro cultivation } \\
\text { time } \\
\text { (days) }\end{array}$} & \multicolumn{4}{|c|}{ Type of flask sealing } \\
\hline & Plastic cap & PVC film & Para-film $®$ & Aluminum foil \\
\hline \multicolumn{5}{|c|}{ Number of shoots } \\
\hline 30 & $1.05 \mathrm{aB}$ & $1.41 \mathrm{aA}$ & $1.45 \mathrm{aA}$ & $1.00 \mathrm{bB}$ \\
\hline 50 & $1.06 \mathrm{aB}$ & $1.34 \mathrm{aAB}$ & $1.48 \mathrm{aA}$ & $1.08 \mathrm{bB}$ \\
\hline 65 & $1.07 \mathrm{aB}$ & $1.37 \mathrm{aAB}$ & $1.59 \mathrm{aA}$ & $1.27 \mathrm{aAB}$ \\
\hline \multicolumn{5}{|c|}{$\mathrm{VC}(\%)=13.18$} \\
\hline \multicolumn{5}{|c|}{ Number of nodes } \\
\hline 30 & $4.80 \mathrm{cAB}$ & $6.43 \mathrm{bA}$ & $6.43 \mathrm{cA}$ & $4.08 \mathrm{cB}$ \\
\hline 50 & $5.78 \mathrm{bBC}$ & $7.32 \mathrm{aAB}$ & $8.03 \mathrm{bA}$ & $4.90 \mathrm{bC}$ \\
\hline 65 & $7.15 \mathrm{aAB}$ & $7.87 \mathrm{aA}$ & $8.88 \mathrm{aA}$ & $5.82 \mathrm{aB}$ \\
\hline \multicolumn{5}{|c|}{$\mathrm{VC}(\%)=11.15$} \\
\hline \multicolumn{5}{|c|}{ Leaf abscission $^{1}(\%)$} \\
\hline 30 & $5.05 \mathrm{bA}$ & $4.58 \mathrm{bA}$ & $2.82 \mathrm{bA}$ & $3.34 \mathrm{bA}$ \\
\hline 50 & $8.76 \mathrm{bA}$ & $9.00 \mathrm{abA}$ & $7.35 \mathrm{bA}$ & $7.50 \mathrm{abA}$ \\
\hline 65 & $21.25 \mathrm{aA}$ & $12.41 \mathrm{aB}$ & $14.30 \mathrm{aAB}$ & $8.95 \mathrm{aB}$ \\
\hline \multicolumn{5}{|c|}{$\mathrm{VC}(\%)=29.61$} \\
\hline
\end{tabular}

Means followed by same small letter in the column and capital on the line do not differ statistically between each other by the Tukey test at $5 \%$ probability.

${ }^{1}$ square root-transformed data $(\mathrm{x}+0.5)$ 
in the culture medium volume was significantly higher in flasks sealed with PVC film, the cultures showed higher number of nodes per adventitious shoot under this condition.

According to works cited above, it is clear that the in vitro responses in function of changes of physical factors such as type of flask sealing depend on the species and the multiplication stage to which the cultures are submitted. For mangaba tree, due to the high leaf abscission (Figure 2) shown in function of the ethylene concentration (PEREIRA NETTO, 2001; PEREIRA NETTO; MCCOWN;

PHARIS, 2003), the type of flask sealing is an important factor to be considered in the establishing of future largescale propagation protocols.

Table 4 - Mean reduction of the culture medium volume (\%) as a function of the type of flask sealing in the first and the second subculture of Hancornia speciosa Gomes explants.

\begin{tabular}{ccccc}
\hline \multirow{2}{*}{ Subcultures } & \multicolumn{4}{c}{ Type of flask sealing } \\
\cline { 2 - 4 } & Plastic cap & PVC film & Para-film ${ }^{\circledR}$ & Aluminum foil \\
\hline $1^{\text {st }}$ & $11.33 \mathrm{~B}$ & $59.33 \mathrm{~A}$ & $11.00 \mathrm{~B}$ & $15.66 \mathrm{~B}$ \\
\hline $2^{\text {nd }}$ & $18.66 \mathrm{~B}$ & $\mathrm{VC}(\%)=53.85$ & $20.00 \mathrm{~B}$ \\
\hline
\end{tabular}

Means followed by same small letter in the column and capital on the line do not differ statistically between each other by the Tukey test at $5 \%$ probability.

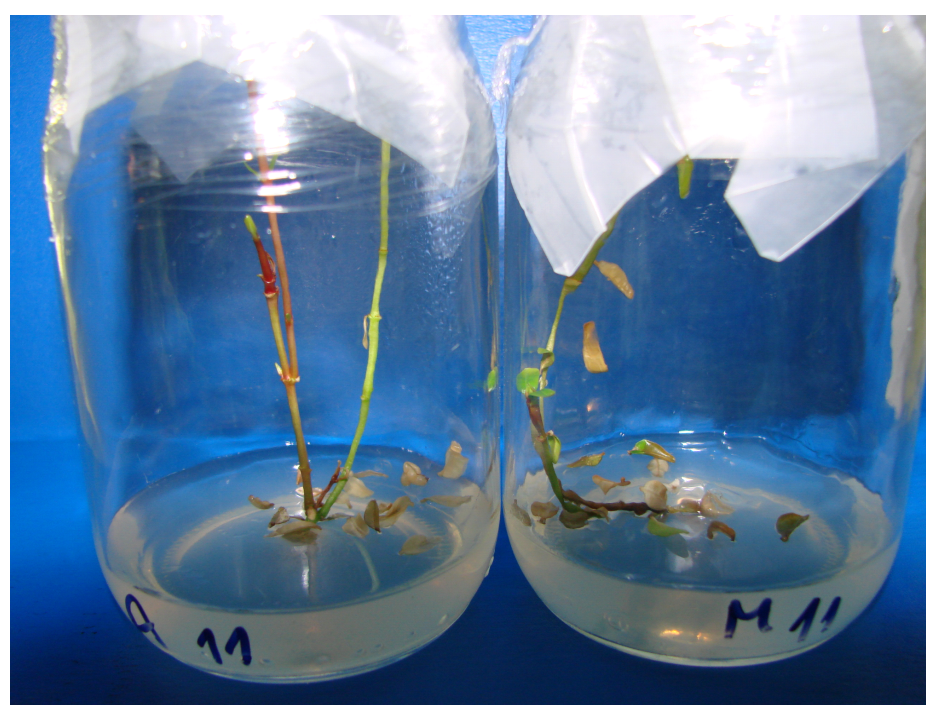

Figure 2 - Leaf abscission in mangaba adventitious shoots regenerated in vitro in the second subculture at 65 days. 


\section{CONCLUSION}

In the establishment phase, adventitious shoots regenerated in flasks sealed with Para-film ${ }^{\circledR}$ and PVC film showed greater number of nodes and Para-film ${ }^{\circledR}$ showed higher number of shoots at 65 days in the first and second subcultures. Median and basal mangaba tree nodal segments induce a higher number of nodes in the first subculture. PVC film induces a greater reduction in the culture medium volume in the first and second subcultures and flasks sealed with plastic cap showed greater leaf abscission at 65 days in the second subculture. The interval subculture of 50 days is suitable for the establishment phase and for the first and second subcultures.

\section{ACKNOWLEDGMENTS}

To the Brazilian Agricultural Research Corporation's (EMBRAPA), to the National Council for Scientific and Technological Development (CNPq) (Process No. 562728/2008-2, 474191/2007-9, 63363/20100 ) and to the Foundation for Support to Innovation, Science and Technology of the State of Sergipe (FAPITEC-SE) for financial support and granting of research fellowships.

\section{REFERENCES}

BANDEIRA, J.M. et al. Diferentes tipos de vedações dos frascos e concentrações de sacarose na micropropagação de Thymus vulgaris L. Revista Brasileira de Biociências, Porto Alegre, v.5, supl. 2, p.472-474, jul. 2007.

BUFFA, W.F. et al. Indução de metabólitos bioativos em culturas de células de Maytemus ticfolia. Eclética Química, São Paulo, v.27, n. especial, s.d., p. 403-416, 2002.

ERIG, A.C.; SCHUCH, M.W. Micropropagação fotoautotrófica e uso da luz natural. Ciência Rural, Santa Maria, v.35, n.4, p.961-965, jul./aug. 2005.

FERREIRA, D.F. SISVAR: a computer statistical analysis system. Ciência e Agrotecnologia, Lavras, v. 35, n.6, p. 1039-1042, 2011.

GONÇALVES, L.A. et al. In vitro propagation of Herreria salsaparrilha Martius (Herreriaceae) as affected by different sealing materials and gaseous exchanges. Plant Cell, Tissue and Organ Culture, Netherlands, v.92, n.3, p.243-250, mar. 2008.
KERBAUY, G.B. Fisiologia Vegetal. Rio de Janeiro: Guanabara Koogan, 2004. 452p.

KOZAI, T.; NGUYEN, Q.T. Photoautotrophic micropropagation of woody and tropical plants. In: JAIN, S.M.; ISHII, K. Micropropagation of woody trees and fruits. Dordrecht : Kluwer Academic, 2003. p.757-781.

LÉDO, A. da S. et al. Cultivo in vitro de sementes de mangaba (Hancornia speciosa Gomes). Ciência e Agrotecnologia, Lavras, v.31, n.4, p.989 -993, jul./ago., 2007.

LEMOS, E.E.P.; BLAKE, J. Leaf abscission in micropropagated sugar apple (Annona squamosa L.). In : LUMSDEN, P.J.; NICHOLAS, J.R. ; DAVIES, W.J. Physiology, growth and development of plants in culture. Dordrecht: Klwer Academic Publishers, 1994. p.232-237.

LEMOS, E.E.P. et al. (Ed.). A cultura da mangaba. Aracaju: Embrapa Tabuleiros Costeiros, 2006. p.125-133.

MACHADO, L.L. et al. Seleção de matrizes e clones de mangabeira para o cultivo in vitro. Pesquisa

Agropecuária Brasileira, Brasília, v.39, n.5, p.431-435, maio 2004.

MOHAMED, M.A.H.; ALSADON, A.A. Influence of ventilation and sucrose on growth and leaf anatomy of micropropagated potato plantlets. Scientia

Horticulturae, Amsterdam, v.123, p.295-300, 2010.

NICOLOSO, F.T.; ERIG, A.C. Efeito do tipo de segmento nodal e tamanho do recipiente no crescimento de plantas de Pfaffia glomerata in vitro. Ciência e Agrotecnologia, Lavras, Edição Especial, p.1499-1506, 2002.

PEREIRA NETTO, A.B. Effect of inhibitors of ethylene biosynthesis and signal transduction pathway on the multiplication of in vitro-grown Hancornia speciosa.

Plant Cell, Tissue and Organ Culture, Netherlands, v.66, n.1, p.1-7, jul. 2001.

PEREIRANETTO, A.B.; MCCOWN, B.H.; PHARIS, R.P. Inhibition of growth of microcultured Hancornia speciosa shoots by $3 \beta$-hydroxylated gibberellins and one of their C-3 deoxy precursors. Plant Cell Reports, Berlin, v.21, n.5, p.491-496, jan. 2003. 
PINHEIRO, C. S. R. et al. Germinação in vitro de mangabeira (Hancornia speciosa Gomez) em diferentes meios de cultura. Revista Brasileira de Fruticultura, Jaboticabal, SP, v. 23, n. 2, p. 413-416, 2001.

FERREIRA, E.G. et al. Frutíferas. In: SAMPAIO, E.V.S.B. et al. (Orgs.). Espécies da flora nordestina de importância econômica potencial. Recife: Associação Plantas do Nordeste, 2005, p.49-100.

SANTANA, J.R.F. et al. Estímulo do comportamento fotoautotrófico durante o enraizamento in vitro de Annona glabra L., II. Aspectos da anatomia da folha antes da aclimatização. Ciência e Agrotecnologia, Lavras, v.32, n.2, p.640-644, mar./abr., 2008.

Effect of different culture tube caps and concentrations of activated charcoal and sucrose on in vitro growth and budding induction of Annona glabra L. Ciência e Agrotecnologia. v.35, n.5, p.916-923, 2011.

SILVAJUNIOR, J.F. da. et al. Recursos genéticos nos tabuleiros costeiros e baixada litorânea. In: SILVA JUNIOR, J.F. da; LEDO, A. da S. (Ed.). A cultura da mangaba. Aracaju: Embrapa Tabuleiros Costeiros, 2006. p.57-74.

SILVA, R.P. da. et al. Otimização de protocolos para regeneração de plantas in vitro de tangerina 'Cleópatra' (Citrus reshni Hort. ex Tan.). Revista Brasileira de Fruticultura, Jaboticabal, v.27 n.3, p.484-487, dec. 2005.

SOARES, F.P. et al. Organogênese direta em explantes caulinares de mangabeira (Hancornia speciosa Gomes). Ciência e Agrotecnologia, Lavras, v.31, n.4, p.1048-1053, jul./ago., 2007. 